\title{
EMERGING INFLUENCERS PROMOTING TRAVEL: THE CASE OF LOCAL TOURISM IN LATVIA
}

\author{
Galina Berjozkina1, Zanete Garanti² \\ 1 Senior Lecturer, City Unity College Nicosia, Nicosia, Cyprus, \\ e-mail: g.berjozkina@cityu.ac.cy \\ ${ }^{2}$ Associate professor, City Unity College Nicosia, Nicosia, Cyprus, \\ e-mail: z.garanti@cityu.ac.cy
}

Received: 24 June 2020 / Revised: 20 July 2020 / Accepted: 25 July 2020 /

Published: 30 November 2020

\begin{abstract}
The presence of social networks has given a chance for social media influencers to emerge. Social media influencers creating and sharing content, endorsed or not, has become a growing marketing trend used by companies, as well as destinations. This paper focuses on travel influencers who, with the help of social networks, particularly Instagram, are promoting local travel in Latvia. In this study, four emerging travel influencers and their posts were retrieved and analysed. The study results show that emerging travel influencers are trying to attract their followers by mostly sharing posts with landscapes and nature, art objects/statues, and nature activities/facilities. However, traditional artwork/objects, religious buildings/objects, and traditional or historic buildings are the pictures achieving the highest engagement rates. Finally, the study also revealed that influencers with a lower number of followers have a higher level of engagement. It is concluded that authenticity and individuality of account, as well as its organic, rather than paid growth, are the key aspects in creating a travel account that followers would engage (like, share and comment on the content). The theoretical and practical implications are discussed.
\end{abstract}

Keywords: influencers, travel, tourism, local travel.

JEL code: M31, L83.

\section{Introduction}

With the growing popularity of social media amongst both individuals and businesses comes the rise of influencer marketers (Garcia-Morales, Martín-Rojas, \& Lardón-López, 2018); (Childers, Lemon, \& Hoy, 2019). Influencer marketers are commonly defined as "a new type of independent third party endorser who shapes audience attitudes through blogs, tweets, and the use of other social media" by (Freberg, Graham, McGaughey, \& Freberg, 2011), the definition used also in the study of (Lou \& Yuan, 2019). The world's most popular influencers gather millions of followers that see influencers as peers and trust their content (Liu et al., 2015) allowing the followers to identify with endorsers (Seunga Venus Jin \& Ryu, 2019), creating engagement (Booth, 2011). These influencers then can form partnerships (Charlton \& Cornwell, 2019) with businesses to endorse products and services and influence the customer decision-making process (Evans, Phua, Lim, \& Jun, 2017); (Ferguson, 2008) (Leal, Hor-Meyll, \& de Paula Pessôa, 
2014) when using the right platforms and content to engage (Hughes, Swaminathan, \& Brooks, 2019). Overall, due to more organic, authentic, and direct communication (Lou \& Yuan, 2019) followers tend to trust influencers more than brand-generated content (Lou, Tan, \& Chen, 2019), and even more than traditional celebrities (S. Venus Jin, 2019).

With the tourism industry being one of the world's largest and most dynamic industries (Aratuo \& Etienne, 2019), influencer marketing has quickly become an important tool for promoting not just products and services but also destinations (Stoldt, Wellman, Ekdale, \& Tully, 2019); (Xu (Rinka) \& Pratt, 2018); (Bokunewicz \& Shulman, 2017). From Youtube, Twitter, Facebook and other social site influencers (Lou \& Yuan, 2019) to Instagram influencers creating travel hashtags (De Veirman, Cauberghe, \& Hudders, 2017), millions of pictures, videos, reviews, and other eWOM information are created about destinations (Backaler, 2018). The use of influencer marketers has become an integral part of the overall destination marketing strategy (Ong \& Ito, 2019); (Gretzel, 2017a).

Although influencers are personalities having a large number of followers on either multiple platforms (e.g. Facebook, Twitter, Youtube, etc.) or only one platform (Lou \& Yuan, 2019), when it comes to destinations, the most active place of communication seems to be Instagram (Vrana, Khan, Karavasilis, Kehris, \& Kydros, 2019), due to its visual nature that allows photo and video editing and sharing (Sheldon \& Bryant, 2016). Apart from visuals, Instagram also promotes the use of hashtags (Gretzel, 2017b), which allows them to situate and archive posts and pictures within a specific genre (Cardell \& Douglas, 2018). As per 2019, there were 452 million posts with \#travel, 96.4 million posts with \#travelphotography and 49.7 million posts with \#travelblogger hashtags on Instagram.

With the conditions that affected the world at the beginning of 2020 due to rapid spread of COVID-19, the international tourism industry has seen a dramatic drop in travel activity (Aloi et al., 2020), but nevertheless local travel activities were allowed and encouraged in the majority of the EU countries, including Latvia, where local travel activity reached new heights. Multiple local travel influencers emerged to inspire followers to explore Latvia and as per June 2020, several hashtags like \#latviatravel (32.2 thousand posts) and \#visitlatvia (106 thousand posts) were being used to promote it. This research in particular focuses on emerging travel influencers in Latvia and aims to explore their role in promoting local travel amongst their followers.

This research aims to address several research gaps. Despite ongoing research in the field of social media marketing, academic research into exploring specifically Instagram as a commonly used site for travel and destination marketing is still limited (Djafarova \& Rushworth, 2017). 
Moreover, a limited number of studies that explore the particular social media site focus on the visual content (Geurin-Eagleman \& Burch, 2016), and the majority of the research has a commercial perspective. Social media and Instagram in particular as a tool is used by businesses to promote their products and services (Abed, 2018), build brand relationships with customers (De Veirman et al., 2017), and promote products and services (Abidin, 2016). This research focuses on emerging individual influencers which rather than promoting commercial interests, promote advice (Casaló, Flavián, \& Ibáñez-Sánchez, 2018), with special focus on local tourism promotion via organic content produced by individual influencers that are also locals (Paül i Agustí, 2018). Finally, the current study focuses on local tourism influencers on Instagram in Latvia, previously less explored countries in academic literature. Therefore, the aim of this research is to explore emerging travel influencers that promote local tourism in Latvia. The main research questions are: (1) what are the types and categories of pictures shared by travel influencers in Latvia that aim to promote local tourism, (2) what are the followers' engagement rates for pictures shared by travel influencers in Latvia, (3) what are the categories and types of pictures that have the highest engagement rates.

\section{Literature review. Influencer marketing in Latvia}

Holders of social accounts with thousands of measurable loyal followers are called digital influencers because their accumulated audience and ability to mobilize their followers to perform actions when needed is given the value of a marketing channel (Abolins, 2018). Influencer marketing is a new approach to marketing, where sales forces both understand and support it. It directly addresses the most common sales barriers within prospective customers and focuses attention on those individuals who advise decision-makers. These people are called influencers, and they are as crucial to the sales process as the prospects themselves (Brown \& Hayes, 2008).

There are some companies that are already extremely effective in identifying and working with their major influencers, yet the sector is still emerging. The traditional marketing is one-way communication, however, with technology, the emergence of influencers becomes possible. Influence requires interaction, and the host of emerging social media enables influence to be exerted across a global audience. Social media include the online technologies and techniques that people use to share opinions, insights, experiences and perspectives (Brown \& Hayes, 2008).

Influencer marketing is a relatively new and emerging trend in Latvia. Only a rare digital influencer in Latvia has the content capacity and high- 
quality follower base that would ensure the advertiser's expected return. To order to develop it and attract new, young influencers, many forums, summits and conferences on this topic have been organized in the last three years. Some companies actively use the services of local influencers, attracting them to participate in the development or promotion of a new product. The panel discussion "Influencer Marketing in Latvia: Reality" in the Riga Comm conference, which took place on October 12, 2018, was dedicated to the topic of Marketing of Digital Influencers in Latvia. The panel discussion was attended by Artūrs Mednis, head of New Black, Denis Ševel̦evs, a project manager for influencer communications in Golin Riga, and Maya Armaneva, a full-time influencer.

On September 19, 2019 at the Latvian National Library (LNL) the educational event "Influencer Literacy" was organized by LNL in collaboration with the University of Latvia, the Faculty of Social Sciences, the Latvian National Commission of UNESCO and the office of the Nordic Council of Ministers in Latvia. The expert's discussion and lecture was dedicated to the nature of the new profession, as well as the importance of media literacy, so that users of social networks can more critically evaluate the consumed content and its impact, for example, when buying the audiovisual content that they see (Zarāne, 2019).

The second biggest event that happened in November 2019 in Latvia was The Women in Travel Summit (WITS). During this event, women travel influencers, bloggers, and industry members come together for a weekend of sharing travel experiences, informative programming, and targeted networking. It was the sixth year that the summit brought together travel's top talent to discuss future innovations, build dynamic collaborations, and change the travel industry worldwide, all while supporting and empowering a diverse community. WITS was organized by Wanderful, a top network for women travellers with a reach of over 40k worldwide (Luper, 2019).

The last and the biggest event that attracted 29,000 people, including industry professionals, was Balttour - the largest Tourism Industry Trade fair that is taking place every year in Riga, Latvia. On January 29, People Work hosted the Business Forum of the region's leading travel trade fair Balttour 2020, where 169 tourism professionals and marketing specialists discussed the current affairs and trends in tourism, influencer marketing, youth travel habits and the industry's best practices ("Par tūrisma aktualitātēm diskutēs "Balttour" forumā", 2020). Artūrs Mednis, a founder of New Black Agency, a new media and digital marketing expert, offered an original presentation on trends in influencer marketing. Specialists discussed the practical influencer marketing in Latvia, promoting various tourism offers, best examples and experience. 


\section{Travel influencers as marketers for destinations}

Social media has presented another degree of individual impact where individuals can establish and add to worldwide networks that cannot be coordinated in the physical world (Rowett, 2019). Travel and tourism is one of the sectors in which influencers have become especially prominent. In the travel and tourism industry, influencers can be used to attract more or different kinds of tourists to a given geographical area and to shape the impression of the destination, among different purposes (Femenia-Serra \& Gretzel, 2020). Although there is no consensus regarding the definition of travel influencers, the commonly used definition explains: "the travel influencer is a person that promotes destinations, services or products, associated with travel by leveraging their social media influence" (Stainton, 2020). Influencer marketing in travel and tourism is on the importance of word-of-mouth. Interpersonal communications were recognized long ago as influential in the tourism industry. (Litvin, Goldsmith \& Pan, 2008) Most influencers in Latvia are nano and micro-influencers. It means that their number of subscribers is $1000-5000$ and $5000-20$ 000. Such influencers have stronger connections with their audience. They usually attract an audience with specific interests (for example, tourism), and since they publish for a smaller audience, they can get more involvement for the post (The State of Influencer Marketing on Instagram in the Baltic States: Estonia, Latvia and Lithuania, 2019). The engagement rate (ER) of these influencers is higher. Travel influencers in Latvia are in 3rd place, after Lifestyle and Photography, with an ER of 4.51\% According to the statistics, the ER of nanoinfluencers in Latvia is $7.80 \%$ and of Micro-influencers is $2.93 \%$. The main influencers in Latvia are women aged 18 to 34 years.

On November 5, the Association of Bloggers and Influencers in Latvia was founded, which would unite industry professionals as well as novice bloggers whose activities meet high-quality standards and professional ethics ("В Латвии основана Ассоциация блогеров и инфлюенсеров", 2018). Digital marketing experts Artūrs Mednis and Deniss Ševel̦ovs admitted that there could be about ten influencers in Latvia, for whom the creation of sponsored content, mostly on Instagram has become a full-time job and the main source of income, while the other several hundred individuals earn in their free time from normal work.

\section{Follower engagement to influencers' content}

Nowadays, organizations as well as destinations, recognize the value of social networks and engagements towards their business success (Dolan, Conduit, Fahy, \& Goodman, 2016) and influential people have become a 
rather important part of society - some like to monitor their content. Not all the social interactions are considered engagement, as it is driven by information consumption, interest immersion, a sense of presence, and social interaction (B. G. Smith \& Gallicano, 2015). Comments and shares can be seen as a more reliable source of measuring engagement with users (Chugh, Patel, Patel, \& Ruhi, 2019). In business context, social media engagement is a tool that allows us to develop business relationships (Hollebeek, 2019) and relationships with customers (Liu et al., 2015).

\section{Methodology}

The aim of the current study is to explore local travel influencers as promoters of local travel in Latvia via posts on Instagram. The primary data source for the research is content created by the identified travel influencers that primarily promote local travel in Latvia, and consists of pictures shared, their classification, location, likes and comments. For the purpose of the study, a database of local travel influencers was created. The authors selected influencers with more than 1000 active posts, with an average of 5 posts per week on Instagram as per June 2020, which allows to select the most active members. Four Instagram influencers were selected for the current study with $925,1126,1170$ and 1637 posts, respectively. Then, the latest 100 posts with pictures from Latvia (excluding posts shared from other locations and videos) from each influencer were selected and included in the study sample. The main methods applied for the study were content (Tiggemann \& Zaccardo, 2018) and visual content analysis (L. R. Smith \& Sanderson, 2015). To categorize photos, the authors followed previous research (Kuhzady \& Ghasemi, 2019) and grouped posts into 13 categories, namely 1) Modern Architecture, 2) Art Object/Statue, 3) Festival/Ritual, 4) Food/Restaurant, 5) Leisure Activity/Facility, 6) Nature/Nature Landscape, 7) Urban Landscape, 8) Religious Building/Object, 9) Traditional Art Work/Object, 10) Traditional or Historic Building, 11) Transport/Infrastructure, 12) Ordinary Scene, and 13) Other.

\section{Results and findings}

For the purpose of analysis for this study, 400 pictures from emerging influencers were retrieved and coded to include in the analysis. The engagement rate varies and depends on the number of likes and comments under a particular post, it means, that it is not affected by the external factors. Only the pictures that were taken in Latvia were included for the study. Content and visual content analysis was applied and pictures were classified 
into one of the twelve groups. For the purpose of answering the first research question, a frequency analysis is presented in Table 1.

Table 1. Frequency of categories (compiled by the authors)

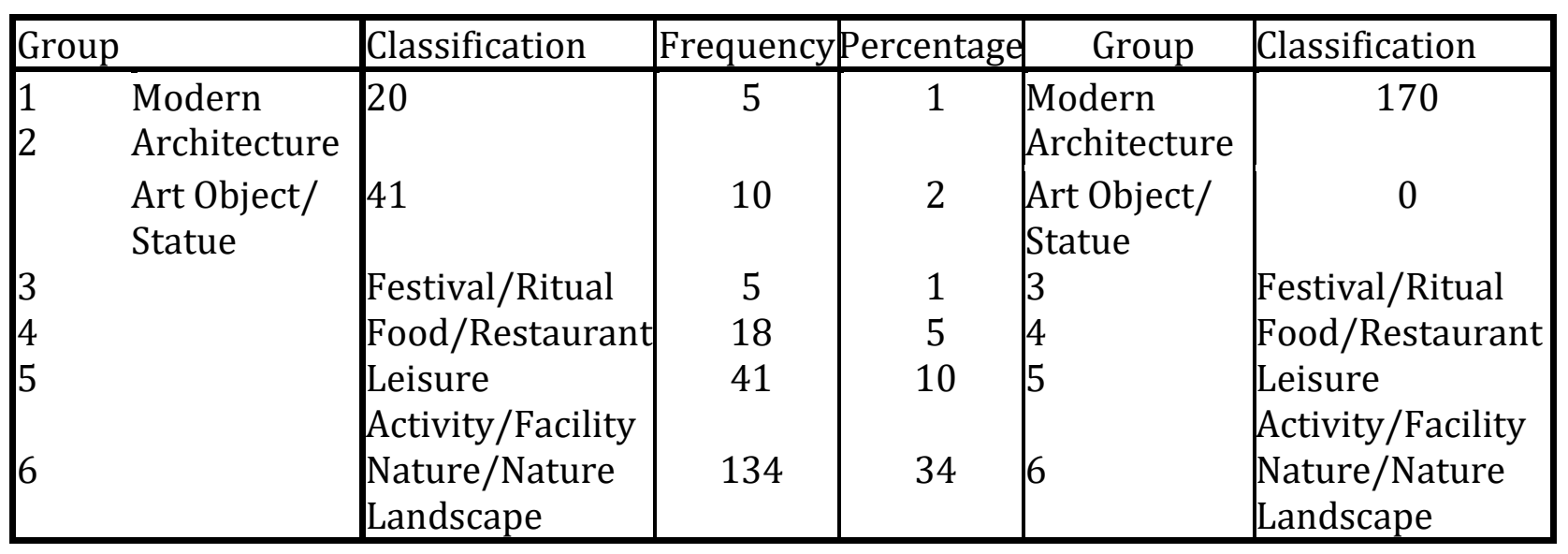

From the frequency analysis above, it is very clear that emerging travel influencers place a great emphasis on sharing pictures with nature and natural landscape scenes, which contributes to 134 out of 400 pictures included in the analysis. Other types of pictures (mostly selfies, selfreflections, one's own family) were shared 46 times and contributed to a total of $12 \%$ of the pictures. Several leisure activities and facilities, including nature walks, water sports, sport facilities were shared 41 times, as well as art objects and statues. Traditional and historical buildings like palaces, village houses, historical city centres around all regions from Latvia contributed to $9 \%$ of total pictures. Pictures of modern architecture, mostly from capital Riga, with scenes of a national library, coast and other significant modern architectural buildings and scenes were shared 20 times as well as food and restaurant images (5\%). The rest of the pictures from categories like transport, infrastructure, religious buildings and objects, festivals and rituals, and others contribute to $16 \%$ of total pictures shared on Instagram by emerging travel influencers that promote local travel in Latvia. It is important to note that the pictures shared are from all regions of Latvia.

The second research question deals with engagement towards shared pictures from the followers' in the form of likes and comments. The standard formula of social media engagement was used for this study, where an engagement rate is calculated as a sum of picture likes and comments, divided by the number of followers and multiplied by a hundred. (The State of Influencer Marketing on Instagram in the Baltic States: Estonia, Latvia and Lithuania, 2019). The summary of engagement indicators is presented in Table 2. 
Table 2. Picture engagement by influencer (compiled by the authors)

\begin{tabular}{|c|c|c|c|c|c|}
\hline Influencer & $\begin{array}{l}\text { Number } \\
\text { of } \\
\text { followers }\end{array}$ & $\begin{array}{c}\text { The average } \\
\text { number of } \\
\text { likes per } \\
\text { picture }\end{array}$ & $\begin{array}{l}\text { The average } \\
\text { number of } \\
\text { comments } \\
\text { per picture }\end{array}$ & $\begin{array}{c}\text { The average } \\
\text { engagement } \\
\text { rate }\end{array}$ & Influencer \\
\hline $\begin{array}{ll}1 & 1050 \\
2 & 9989 \\
3 & \\
4 & \\
\text { Average } \\
\text { Influencer }\end{array}$ & $\begin{array}{c}84 \\
446 \\
1638 \\
12258 \\
6234 \\
\text { Number } \\
\text { of } \\
\text { followers }\end{array}$ & \begin{tabular}{|c|}
2.71 \\
64.85 \\
85 \\
283 \\
225 \\
The average \\
number of \\
likes per \\
picture
\end{tabular} & $\begin{array}{c}8.21 \\
5.12 \\
5.25 \\
9.86 \\
20.67 \\
\text { The average } \\
\text { number of } \\
\text { comments } \\
\text { per picture }\end{array}$ & $\begin{array}{c}1 \\
2 \\
6.99 \\
2.39 \\
5.68 \\
\text { The average } \\
\text { engagement } \\
\text { rate }\end{array}$ & \begin{tabular}{|c}
170 \\
0 \\
3 \\
4 \\
Average \\
Influencer
\end{tabular} \\
\hline
\end{tabular}

The four emerging travel influencers have on average 6 thousand followers, although there is a large variation in the number of followers from 1 to 12 thousand. In this research, the frequency of posts does not affect the engagement rate. The average number of likes and comments indicate that there are on average 10 times more likes than comments. Therefore, the average engagement rate is 5.68, showing that followers in Latvia have a medium activity and tendency to respond to the posts. Interestingly, the lower the number of followers an influencer has, the higher engagement rate it has, and influencers with 12 thousand followers, therefore, have the lowest engagement rate amongst all standing at 2.39. On the other hand, the influencer with the lowest number of followers has the highest engagement rates.

In regard to the third research question, which deals with engagement rates per picture categories, Figure 1 is prepared to analyse followers' engagement within previously defined categories of pictures.

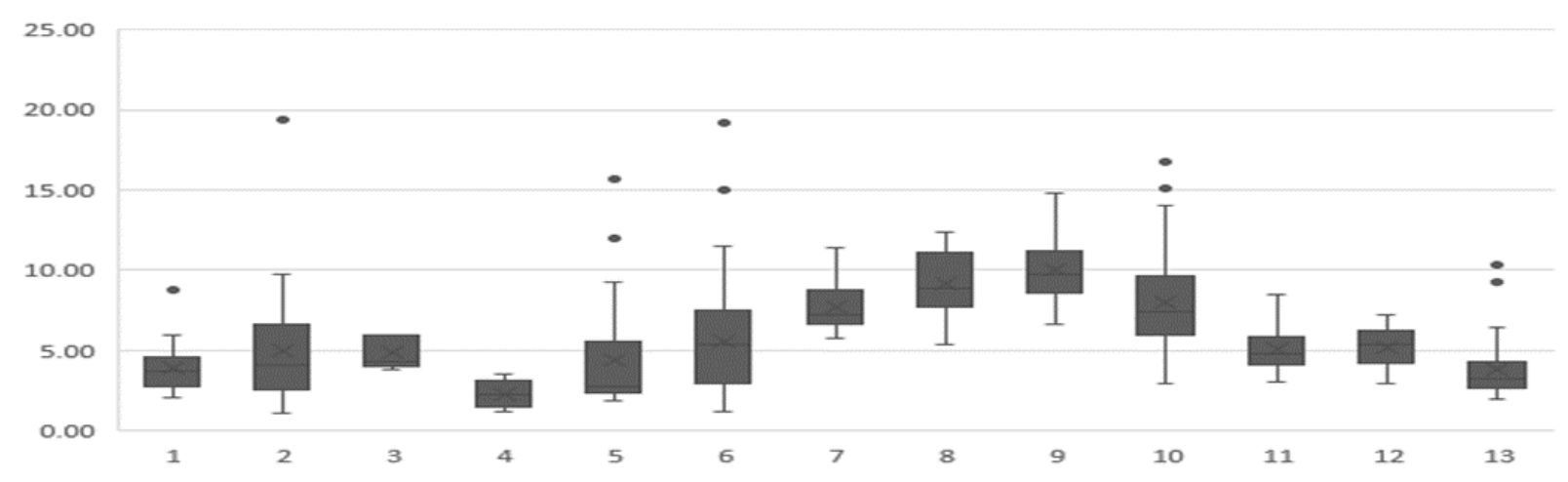

Fig. 1. Followers' engagement per category (compiled by the authors) 
Despite the fact that nature and nature landscapes category has the largest number of pictures shared by influencers, it does not have an as high number of engagement as the categories of traditional artwork/object, religious buildings/objects, and traditional or historic buildings, which are the three categories of shared pictures that followers have engaged the most. The lowest engagement is for food / restaurant and other pictures (selfies, one's own family, self-reflections) and modern architecture. The implications of these findings will be discussed further on.

\section{Conclusions and discussions}

The purpose of the current research was to explore emerging travel influencers that promote local tourism in Latvia. For the purpose of this study, four emerging travel influencers were identified on Instagram and the last 100 posts shared from Latvia were retrieved and combined in the database (total of 400 posts). Moreover, posts were classified in 12 categories and analysis tools were applied.

The travel influencer sector is still emerging in Latvia, there are currently over 10 accounts on Instagram that local influencers have, and these accounts relate to the travel and tourism industry. However, the study has shown that even with a small amount of such influencers, people are still interested in travelling across Latvia and sharing their photos to influence followers. Compared with world well-known tourism influencers, Latvian tourism influencers have a smaller audience and recognition. Despite the small number of tourism influencers in Latvia, they do a great job and attract a considerable amount of followers to their Instagram accounts. The four travel influencers included in this study have totally 25 thousand followers on Instagram.

The first research question is: what are the types and categories of pictures shared by travel influencers in Latvia that aim to promote local tourism. In terms of travel and tourism, typical Latvians are not particularly interested in observing and following the influencers whose posts are made in places that everyone knows about. By posting this content, influencers tend to annoy their followers. Followers want to see something new, something less familiar, or less explored when it comes to tourism. They are more interested in learning and discovering new places to travel around Latvia than about all the long-known ones. It is interesting to note that in the posts published, there were landscapes and nature, which were less familiar to a typical Latvian. Influencers are focused on attracting the attention of followers, as a consequence of the publication of places less known in Latvia. The analysis of the 400 posts shared by emerging travel influencers shows 
that the majority of posts shared were the pictures of nature and landscape, which is typical for travel influencers ((Yllmaz, Sezerel, \& Uzuner, 2020). A smaller number of posts were pictures of other categories (selfies, family etc.), art objects/statues, and nature activities/facilities.

Secondly, the research question regarding what is the followers' engagement rates for pictures shared by travel influencers in Latvia was analysed. Engagement rates per picture were calculated from information retrieved from Instagram (picture likes, comments and total number of followers), and an analysis reveals that influencers have average rates of engagement, and moreover influencers with a lower number of followers have a higher number of engagement, which is in line with previous studies revealing that organic accounts and posts have higher effectiveness (Aydin, 2020). The average engagement rate for four influencers was 5.68, while the engagement rate for the account with the lowest number of followers was 8.21.

Finally, the third research question is what are the categories and types of pictures that have the highest engagement rates? An analysis reveals that traditional artwork/object, religious buildings/objects, and traditional or historic buildings are the categories achieving the highest engagement rate. Previous studies reveal that traditional ethnography allows us to create authentic travel accounts on social media (Miotti, 2019), which is one of the reasons to explain high activity towards traditional and religious posts.

Several implications can be drawn from the results of the current study. First, it is suggested that travel influencers achieve a variety in their posts to attract a wider local audience. Currently, the majority of the posts are nature/nature landscape, but these are not the posts having the highest engagement. Influencers should share their pictures from a variety of categories, including traditional places, buildings, art, objects and religious attractions that have higher follower engagement. Given this research, it is recommended that in order to achieve higher engagement, influencers should focus on organic and authentic content that would allow them to stand out from the majority of traditional influencer accounts that share similar information and travel destinations. Finally, travel influencers have a chance to become international promoters of Latvian travel destinations and have international recognition if they work towards content that attracts the attention of international travellers.

The current study has several limitations. It only focuses on emerging travel influencers in Latvia that actively work on Instagram and last 100 posts from four travel influencers were included in analysis, which limits the scope of the study results. A wider geographical area and a larger number of influencers and posts can be considered for future studies. 


\section{References}

1. A.W. Olsen \& Partners. (2019). The State of Influencer Marketing on Instagram in the Baltic States: Estonia, Latvia and Lithuania [Ebook] (pp. 5, 11,14-16). Riga.

2. Abed, S. (2018). An empirical examination of Instagram as an s-commerce channel. Journal of Advances in Management Research, 15(2), 146-160.

3. Abidin, C. (2016). Visibility labour: Engaging with Influencers' fashion brands and\# OOTD advertorial campaigns on Instagram. Media International Australia, 161(1), 86-100.

4. Abolins, U. (2018). Digitālo influenceru mārketings Latvijāa: problēmu mākts un laipošana krēslas zonā [Blog]. Retrieved from https://www.linkedin.com/pulse/digit\%C4\%81lo-influencerum\%C4\%81rketings-latvij\%C4\%81-probl\%C4\%93mu-m\%C4\%81kts-uldisabolins/

5. Aloi, A., Alonso, B., Benavente, J., Cordera, R., Echániz, E., González, F., Sañudo, R. (2020). Effects of the COVID-19 Lockdown on Urban Mobility: Empirical Evidence from the City of Santander (Spain). Sustainability: Science Practice and Policy, 12(9), 3870.

6. Aratuo, D. N., \& Etienne, X. L. (2019). Industry level analysis of tourism-economic growth in the United States. Tourism Management, 70, 333-340.

7. Aydin, G. (2020). Social media engagement and organic post effectiveness: A roadmap for increasing the effectiveness of social media use in hospitality industry. Journal of Hospitality Marketing \& Management, 29(1), 1-21.

8. Backaler, J. (2018). What's Coming: The Future of Influencer Marketing. In Digital Influence (pp. 187-201). Springer.

9. Bokunewicz, J. F., \& Shulman, J. (2017). Influencer identification in Twitter networks of destination marketing organizations. Journal of Hospitality and Tourism Technology, 8(2), 205-219.

10. Booth, N. (2011). Mapping and leveraging influencers in social media to shape corporate brand perceptions. Corporate Communications: An International Journal, 16(3), 184-191.

11. Brown, D., \& Hayes, N. (2008). Influencer Marketing. Routledge.

12. Cardell, K., \& Douglas, K. (2018). Visualising lives: 'the selfie' as travel writing. Studies in Travel Writing, 22(1), 104-117.

13. Casaló, L. V., Flavián, C., \& Ibáñez-Sánchez, S. (2018). Influencers on Instagram: Antecedents and consequences of opinion leadership. Journal of Business Research. doi: 10.1016/j.jbusres.2018.07.005

14. Charlton, A. B., \& Cornwell, T. B. (2019). Authenticity in horizontal marketing partnerships: A better measure of brand compatibility. Journal of Business Research, 100, 279-298.

15. Childers, C. C., Lemon, L. L., \& Hoy, M. G. (2019). \# Sponsored\# Ad: Agency Perspective on Influencer Marketing Campaigns. Journal of Current Issues \& Research in Advertising, 40(3), 258-274.

16. Chugh, R., Patel, S. B., Patel, N., \& Ruhi, U. (2019). Likes, comments and shares on social media: exploring user engagement with a state tourism Facebook page. International Journal of Web Based Communities, 15(2), 104-122.

17. De Veirman, M., Cauberghe, V., \& Hudders, L. (2017). Marketing through Instagram influencers: the impact of number of followers and product divergence on brand attitude. International Journal of Advertising, 36(5), 798-828. 
18. Djafarova, E., \& Rushworth, C. (2017). Exploring the credibility of online celebrities' Instagram profiles in influencing the purchase decisions of young female users. Computers in Human Behavior, 68, 1-7.

19. Dolan, R., Conduit, J., Fahy, J., \& Goodman, S. (2016). Social media engagement behaviour: a uses and gratifications perspective. Journal of Strategic Marketing, 24(3-4), 261-277.

20. Evans, N. J., Phua, J., Lim, J., \& Jun, H. (2017). Disclosing Instagram Influencer Advertising: The Effects of Disclosure Language on Advertising Recognition, Attitudes, and Behavioral Intent. Journal of Interactive Advertising, 17(2), 138-149.

21. Ferguson, R. (2008). Word of mouth and viral marketing: taking the temperature of the hottest trends in marketing. Journal of Consumer Marketing, 25(3), 179-182.

22. Freberg, K., Graham, K., McGaughey, K., \& Freberg, L. A. (2011). Who are the social media influencers? A study of public perceptions of personality. Public Relations Review, 37(1), 90-92.

23. Garcia-Morales, V. J., Martín-Rojas, R., \& Lardón-López, M. E. (2018). Influence of social media technologies on organizational performance through knowledge and innovation. Baltic Journal of Management. doi:10.1108/bjm-04-2017-0123

24. Geurin-Eagleman, A. N., \& Burch, L. M. (2016). Communicating via photographs: A gendered analysis of Olympic athletes' visual self-presentation on Instagram. Sport Management Review, 19(2), 133-145.

25. Gretzel, U. (2017a). Influencer marketing in travel and tourism. In Advances in Social Media for Travel, Tourism and Hospitality (pp. 147-156). Routledge.

26. Gretzel, U. (2017b). \# travelselfie: a netnographic study of travel identity communicated via Instagram. In Performing Cultural Tourism (pp. 129-142). Routledge.

27. Hollebeek, L. D. (2019). Developing business customer engagement through social media engagement-platforms: An integrative S-D logic/RBV-informed model. Industrial Marketing Management, 81, 89-98.

28. Hughes, C., Swaminathan, V., \& Brooks, G. (2019). Driving Brand Engagement Through Online Social Influencers: An Empirical Investigation of Sponsored Blogging Campaigns. Journal of Marketing, 83(5), 78-96.

29. Jin, S. V. (2019). Instafamous and social media influencer marketing. Marketing Intelligence \& Planning, 37(5), 567-579.

30. Jin, S. V., \& Ryu, E. (2019). Celebrity fashion brand endorsement in Facebook viral marketing and social commerce: Interactive effects of social identification, materialism, fashion involvement, and opinion leadership. Journal of Fashion Marketing and Management: An International Journal, 23(1), 104-123.

31. Kuhzady, S., \& Ghasemi, V. (2019). Pictorial Analysis of the Projected Destination Image: Portugal on Instagram. Tourism Analysis, 24(1), 43-54.

32. Leal, G. P. A., Hor-Meyll, L. F., \& de Paula Pessôa, L. A. G. (2014). Influence of virtual communities in purchasing decisions: The participants' perspective. Journal of Business Research, 67(5), 882-890.

33. Litvin, S. W., Goldsmith, R. E., \& Pan, B. (2008). Electronic word-of-mouth in hospitality and tourism management. Tourism Management, 29(3), 458-468.

34. Liu, S., Jiang, C., Lin, Z., Ding, Y., Duan, R., \& Xu, Z. (2015). Identifying effective influencers based on trust for electronic word-of-mouth marketing: A domainaware approach. Information Sciences, 306, 34-52. 
35. Lou, C., \& Yuan, S. (2019). Influencer Marketing: How Message Value and Credibility Affect Consumer Trust of Branded Content on Social Media. Journal of Interactive Advertising, 19(1), 58-73.

36. Lou, C., Tan, S.-S., \& Chen, X. (2019). Investigating Consumer Engagement with Influencer- vs. Brand-Promoted Ads: The Roles of Source and Disclosure. Journal of Interactive Advertising, 1-18.

37. Luper, K. (2019). Women in Travel Summit, Riga Latvia 2019 | Hostel Management Discussion. Retrieved from https://hostelmanagement.com/forums/women-travelsummit-riga-latvia-2019.html

38. Miotti, T. (2019). HOW TO BE AUTHENTIC: a visual social semiotic approach to travel photography on Instagram. Retrieved from http://lup.lub.lu.se/studentpapers/record/8987539/file/8987547.pdf

39. Ong, Y. X., \& Ito, N. (2019). 'I Want to Go There Too!' Evaluating Social Media Influencer Marketing Effectiveness: A Case Study of Hokkaido's DMO. In Information and Communication Technologies in Tourism (pp. 132-144). Springer.

40. Par tūrisma aktualitātēm diskutēs "Balttour" forumā. (2020). Retrieved from http://www.balttour.lv/forum/en/news_8.php

41. Paül i Agustí, D. (2018). Characterizing the location of tourist images in cities. Differences in user-generated images (Instagram), official tourist brochures and travel guides. Annals of Tourism Research, 73, 103-115.

42. Rowett, P. (2019). Working with Digital Influencers in Tourism. Retrieved from https://tourismeschool.com/blog/a-destination-marketers-guide-to-workingwith-digital-influencers/

43. Sheldon, P., \& Bryant, K. (2016). Instagram: Motives for its use and relationship to narcissism and contextual age. Computers in Human Behavior, 58, 89-97.

44. Smith, B. G., \& Gallicano, T. D. (2015). Terms of engagement: Analyzing public engagement with organizations through social media. Computers in Human Behavior, 53, 82-90.

45. Smith, L. R., \& Sanderson, J. (2015). I' m Going to Instagram It! An Analysis of Athlete Self-Presentation on Instagram. Journal of Broadcasting \& Electronic Media, 59(2), 342-358.

46. Stainton, D. (2020). What is an Influencer? Travel Influencer Defined - Tourism Teacher. Retrieved from https://tourismteacher.com/travel-influencer-definition/

47. Stoldt, R., Wellman, M., Ekdale, B., \& Tully, M. (2019). Professionalizing and Profiting: The Rise of Intermediaries in the Social Media Influencer Industry. Social Media + Society, 5(1), 2056305119832587.

48. Tiggemann, M., \& Zaccardo, M. (2018). 'Strong is the new skinny': A content analysis of\# fitspiration images on Instagram. Journal of Health Psychology, 23(8), 10031011.

49. Vrana, V., Khan, F., Karavasilis, G., Kehris, E., \& Kydros, D. (2019). Indian Cultural Institutions on Instagram. In Strategic Innovative Marketing and Tourism (pp. 693701). Springer International Publishing.

50. Xu (Rinka), X., \& Pratt, S. (2018). Social media influencers as endorsers to promote travel destinations: an application of self-congruence theory to the Chinese Generation Y. Journal of Travel \& Tourism Marketing, 35(7), 958-972.

51. Yılmaz, M., Sezerel, H., \& Uzuner, Y. (2020). Sharing experiences and interpretation of experiences: a phenomenological research on Instagram influencers. Current Issues in Tourism, 1-8. 
52. Zarāne, A. (2019). Ikviens no mums ir ietekmētājs - EPALE - European Commission. Retrieved from https://epale.ec.europa.eu/lv/blog/ikviens-no-mums-irietekmetajs

53. В Латвии основана Ассоциация блогеров и инфлюенсеров. (2018). Retrieved from https://rus.delfi.lv/news/daily/latvia/v-latvii-osnovana-associaciyablogerov-i-inflyuenserov.d?id=50574681\&all=true 